\title{
MATHEMATICAL CRITICAL THINKING ABILITY REVIEWED FROM SELF-EFFICACY IN DISCOVERY LEARNING
}

\author{
Ghina Nafs Nugroho ${ }^{a}$, Onwardono Rit Riyanto ${ }^{b x}$ \\ SD Negeri 1 Sokanagera ${ }^{a}$, Postgraduate UNNES ${ }^{b}$ \\ ${ }^{x}$ Corresponding author: onwardono11@gmail.com
}

\begin{abstract}
Critical thinking skills are needed as competitive capital in the future. Critical thinking ability is the most important goal taught in mathematics learning. One of the supporting factors for students' success in mathematical critical thinking is the level of self-efficacy. This study aims to determine whether there is an increase in mathematical critical thinking skills in terms of self-efficacy in discovery learning learning. The research design used is mastered experiments using quantitative data. The population of this study was class VII Cirebon 8 Public Middle School and the sample taken was class VII B. The results showed that (1) self-efficacy students'had an average of 78.14 which was quite good. (2) Mathematical critical thinking skills of students have increased based on the results of pre-tests and p-test. (3) There is an increase in students 'critical thinking skills after learning which is viewed from self-efficacy students'.
\end{abstract}

Keywords: Mathematical critical thinking ability, self-efficacy

\section{INTRODUCTION}

Critical thinking is the most important component in preparing millennial generations in order to compete in today's dynamic era. Some studies reveal that mathematics as a science is strategic and has the potential to develop critical thinking skills (Kusaeri and Aditomo, 2018: 574). Therefore, mathematics should be occupied by young millennials who will compete in the 21 st century.

Cornelus as quoted by Abdurrahman (1999: 253) says that there are many reasons for the need for students to study Mathematics, namely (1) Mathematics is a means of thinking that is clear and logical, (2) Mathematics is a means of solving everyday life problems, (3) Mathematics is a means to recognize patterns of relations and generalization of experience, (4) Mathematics is a means to develop creativity, and (5) Mathematics is a means to increase awareness of cultural development (Parisa, 2015: 2).

Mathematical critical thinking ability is the ability to think in solving mathematical problems involving mathematical knowledge, mathematical reasoning and mathematical evidence (Piawa, 2010: 552). The ability to think critically is basically the ability to be able to consider the information obtained with the aim of being able to make decisions about what he will do. (Hardiyanto, 2018: 117)

Important things found in students still have a sense of reluctance to ask questions about the subject matter to the teacher verbally. Fear is because some students don't ask when they feel they don't understand the lesson so that students have low impact understanding. Teachers who often use learning with lecture models become one of the reasons critical thinking of students is difficult to improve. Students' mathematical critical 
thinking skills can increase by providing opportunities for students to develop mathematical mindsets.

Students of class VII A of SMP Negeri 8 Kota Cirebon were still met by students who found it difficult to develop students' thinking and feeling power to understand mathematics. Many students are embarrassed to ask when the teacher has finished delivering mathematics material. Fear and shame are factors that students do not ask when they find it difficult to understand mathematics. Factors in students as an effort to regulate actions to achieve certain goals are called self-efficacy.

Self-efficacy (Erwanto, Maryatmi, and Budiyanto, 2018: 41) are mental models shown by individuals to express themselves to behavior, beliefs about how much they are able to do the task to get certain results. Students with characteristics self-efficacy high will find it easy for them to choose and use learning strategies and vice versa.

Theself-efficacy perceived refers to the belief in a person's ability to regulate and implement the actions needed to achieve goals. According to Bong and Skaalvik (2003: 5) self-efficacy influences a person's chosen attitude as an effort to deal with difficulties to achieve goals. Self-efficacy also provides students with a sense of agency to motivate their learning through the use of selfregulating processes such as goal setting, self-monitoring, self-evaluation, and strategy use (Zimmerman, 2000: 87).

Bandura states that self-efficacy is concerned with confidence in the ability of a student to organize and implement a series of actions needed to produce the desired achievement. But from the observations of researchers that students still lack confidence in their academic abilities in answering mathematical questions. Students' lack of confidence can also be seen from answers that cheat from other students and are afraid to answer teacher questions when asked about their answers. Self-efficacy of students can be disrupted due to lazy learning habits, easy giving up, easy to find difficult questions or tests, not optimizing intelligence.

\section{LITERATURE STUDY}

Critical thinking according to Fisher, quoted by Ikhsan et al. (2017: 235 ), is a process that is centered or empties into making and drawing conclusions or logical decisions about what actions should be taken and what to believe or believe. This indicates that the characteristics of critical thinking are closely related to awareness of one's own ability to develop various ways that might be taken in solving a problem. Critical thinking includes the ability to read with understanding and identifying necessary and unnecessary materials. Critical thinking also means being able to draw conclusions from a set of data and express inconsistencies and contradictions in a set of data (Nugraha \& Mahmudi, 2015).

Critical thinking ability has characteristics including (Fakhriyah, 2014: 99), namely: (1) Looking for clear statements from each statement; (2) Looking for reasons; (3) Trying to know information well; (4) Using sources that have credibility and mention them; (5) Paying attention to the overall situation and conditions; (6) Trying to remain relevant to the main idea; (7) Given original and fundamental interests; (8) Looking for alternatives; (9) Be open and think openly; (10) Taking a position when there is sufficient evidence to do something; (11) Look for as many explanations as possible if possible; (12) 
Acting systematically and regularly with parts of the overall problem; and (13) Sensitive to the level of knowledge and expertise of others.

Albert Bandura (in Feist \& Gregory, 2008: 415) definesor selfefficacy. Self-efficacy as a person's belief in his ability to do some form of control of the person's own functions and events in the environment. self-efficacy Students 'towards mathematics (Novferma. 2016) is students' self-confidence in their ability to solve problems, complete tasks without comparing with other people's abilities.

Gani (2015: 337) that students' perceptions of their abilities are able to build strength to keep learning while fostering like and like to learn. Cervone and Lawrence (2012: 257) say that individuals who have high self-efficacy show greater effort and perseverance and display a lower self-esteem attitude than individuals who have self-efficacy low.

According to Albert Bandura, selfefficacy is a person's assessment of his ability to arrange the actions needed to complete specific tasks at hand. Selfassessment of a person is closely related to self-efficacy. Strong beliefs and feelings and control of emotions are the basic concepts of self-efficacy. Thus, selfefficacy is a subjective perception problem.

\section{RESEARCH METHODOLOGY \\ a. Population and Research Samples The}

population of the study was all VII grade students in the even semester of the 2018/2019 academic year in Cirebon 8 Public Middle School 8 classes.

The sampling technique in this study was purposive sampling, namely by determining the class to be studied directly. The researcher took the sample as a research subject, namely class VII B. b. Research Methods and Design
The research method used in this study was a quasi-experimental method that is a method that does not allow the researcher to fully control the experimental variables and conditions (Sandjaja and Albertus, 2006: 125). The design of this study is all the processes needed in planning and conducting research, in this study using the research design, "One Shot Case Study" which is an approach model that uses one time data collection at one time. (Sugiyono, 2007: 110).

\section{c. Research Instruments}

To obtain data in this study, two types of instruments were used which consisted of a description of critical thinking skills to determine the ability of critical thinking skills of class VII B students of Cirebon Middle School 8 using discovery learning.

\section{d. Data Analysis Techniques Data}

analysis techniques used in this study are quantitative analysis techniques using data tests of mathematical critical thinking skills and questionnaire data self-efficacy student. Some statistical tests used in this study are normality test, homogeneity test, paired sample $t$ test.

\section{RESULTS AND DISCUSSION}

a. Description of the Results of Critical Thinking Ability Tests

Data on students' mathematical critical thinking skills are obtained from the results of mathematical tests with indicators of critical thinking skills. From student answers related to the test can be seen through Table 1 below.

Table 1 Description of the critical thinking skills of students

\begin{tabular}{lrr}
\hline & Pre-test & Post-test \\
\hline $\mathrm{N}$ & 26 & 26 \\
Range & 48.49 & 34.22 \\
Minimum & 24.38 & 45.78 \\
Maximum & 43.87 & 88.24 \\
Mean & 46.79 & 75.66 \\
\hline
\end{tabular}


From the calculation description thinking skills Mathematically critical obtained from the pre-test and post-test as shown in table 2. Pre-test mathematical critical thinking ability is known to be an average of 46.79 , the maximum score is 43.87 and the minimum score is 24.38. Unlike the results pre-test before learning there was a change in mathematical critical thinking skills in terms of the results post-test. The posttest results of mathematical critical thinking skills obtained an average yield of 75.66, a maximum score of 88.24 , and a minimum score of 45.78 .

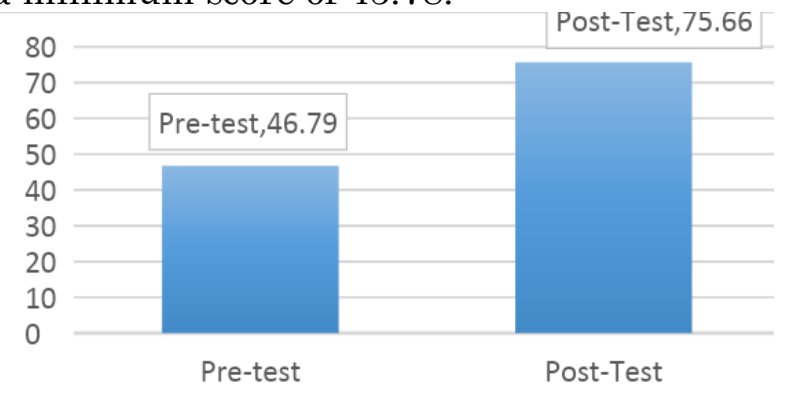

Diagram 1 Comparison of mathematical critical thinking skills

The differences in the results of the pre-test and post-test mathematical critical thinking skills are shown in diagram 1 that the average post-test scores of students are better than the average scores pre-test. The ability of students after learning does seem obvious from the way students answer so students have better grades than the previous test. Increasing the ability of mathematical critical thinking needs to be tested using a statistical formula to provide more definite results.

b. Description of Questionnaire for SelfEfficacy

Data ofself-efficacy student obtained from the results of questionnaires. The results of the questionnaire self-efficacy were student then calculated and analyzed using the SPSS V20 Software. The descriptive calculation of the questionnaire self-efficacy student's can be seen through the following table.

Table 2 Description of Self-efficacy

\begin{tabular}{lr}
\multicolumn{2}{c}{ Student } \\
\hline $\mathrm{N}$ & Questionnaire \\
Range & 26 \\
Minimum & 30.21 \\
Maximum & 56.48 \\
Mean & 86.27 \\
\hline
\end{tabular}

From Table 1 above it is known that the average questionnaire is selfefficacy student78.14, maximum score is 86,27 , and a minimum score of 56.48. Based on the results of the questionnaires self-efficacy students' then the data are categorized as the results of calculations self-efficacy student such as the following table.

Table 3 Classification of Self Efficacy

\begin{tabular}{lll}
\hline \multirow{2}{*}{$\begin{array}{c}\text { Category Self } \\
\text { Efficacy }\end{array}$} & \multicolumn{2}{c}{$\begin{array}{c}\text { Number of } \\
\text { Students }\end{array}$} \\
\cline { 2 - 3 } & \multicolumn{1}{c}{ F } & \multicolumn{1}{c}{$\%$} \\
\hline Very High & 7 & 27 \\
High & 14 & 54 \\
Moderate & 5 & 19 \\
Total & 26 & 100 \\
\hline
\end{tabular}

Based on Table 3 there are three categories of self-efficacy student which are very high, high, and moderate. The high category has the highest frequency of 14 students compared to the other categories. self-efficacy is Student classified as good obtained from questionnaires to students.

c. Normality and Homogeneity

Test The normality test using the help of SPSS software is using the test Kolmogorov Smirnov. This testing criteria uses a significance level or alpha of $5 \%(0.05)$. If the results of the calculation of the normality test using SPSS state a significance value of more than $5 \%$ or 0.05 , the research data is normally distributed. 
Table 4 Test of Kolmogorov-Smirnov

Test of Kolmogorov-Smirnov OneSampleTest

NormalNormalPar Mean 33.0550 ameters ${ }^{a, b}$ Std. Deviation 8,95825 Absolute , 115

Most Extreme Positive , 115 Differences Negative - 088

Kolmogorov-Smirnov Z , 832

Asymp. Sig. (2-tailed) , 494

Based on the results of the calculation of the normality test in Table 4 , it can be seen that the significance is 0.494. Because the significance is more than a or $0.494>0.05$, it can be concluded that the data on students' critical thinking abilities are normally distributed.

Homogeneity Test Homogeneity tests are used to determine whether some populations are the same or not. This test is carried out as a prerequisite foranalysis independentof the sample test. The calculation results using the SPSS program help and obtained the output in Table 5 below.

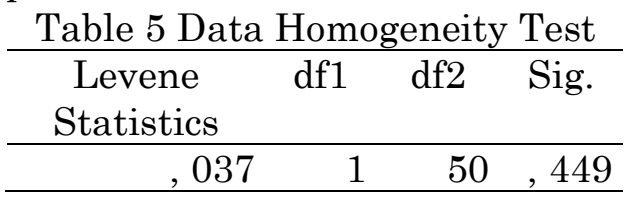

Based on the output in Table 5, it can be seen that the significance value is 0.449 . Because the significance is more than a or $0.449>0.05$, it can be concluded that the research data comes from a homogeneous population. The results of testing for normality and homogeneity state a significance of more than 0.05 so that the hypothesis test can be used parametric test with a test formula paired sample t-test.

d. Test for Improvement of Critical Thinking Ability

To find out the improvement of mathematical critical thinking skills in class VII B after learning Discovery learning is used the formula of paired sample t-test. The paired sample t-test test was used to show the paired samples experienced significant or no changes.

This paired sample t-test test uses criteria if more than a, so there is no increase in mathematical critical thinking skills in class VII B. Testing for paired sample t-test was done using SPSS V20 software. The results of the calculation are paired sample $t$-test shown in the table below in.

Table 6 Output paired sample t-test

\begin{tabular}{|c|c|c|c|c|c|c|c|c|}
\hline \multicolumn{9}{|c|}{ Paired Differences } \\
\hline & \multirow[t]{2}{*}{ Mean } & \multirow{2}{*}{$\begin{array}{c}\text { Std. } \\
\text { Deviation }\end{array}$} & $\begin{array}{l}\text { Std. } \\
\text { Error }\end{array}$ & $\begin{array}{r}95 \% \\
\text { Inte } \\
\text { Di }\end{array}$ & $\begin{array}{l}\text { dence } \\
\text { f the } \\
\text { ice }\end{array}$ & \multirow[b]{2}{*}{$\mathrm{t}$} & \multirow[b]{2}{*}{$\mathrm{df}$} & \multirow[b]{2}{*}{$\begin{array}{l}\text { Sig. }(2- \\
\text { tailed) }\end{array}$} \\
\hline & & & Mean & Lower & Upper & & & \\
\hline Pai & Pretest- & 4.761 & & & & 4.70 & 5 & 0.000 \\
\hline r 1 & Posttest & $\begin{array}{l}1.011 \\
6.425 \\
4.342\end{array}$ & & & & 0 & 0 & \\
\hline
\end{tabular}


Value of significance based on Table 6 unknown 0,000. In other words, there is a change in the value of the pre-test and post-test mathematical critical thinking skills. Based on the descriptive test of mathematical critical thinking ability it was proven that thevalue post-test of critical thinking skills was mathematically higher than the value pre-test of students' mathematical critical thinking skills.

\section{Discussion}

This research was conducted in Cirebon City Public Middle School by taking a sample of class VII B as many as 26 students. The purpose of this study was to determine the mathematical critical thinking skills of class VII B in terms of self-efficacy after the application of model discovery learning. The research data includes tests of critical thinking skills and questionnaires self-efficacy student. The results of the research data test using quantitative analysis techniques with the formula for normality, homogeneity, and paired sample t-test.

The mathematical critical thinking ability of students in the pre-test results tends to produce results that students lack mathematical critical thinking skills. This is indicated by the students' answers regarding the questions that did not write their answers completely. Students tend to write answers according to their wishes and do not pay attention to the questions. However, after post-test mathematical critical thinking skills there were better changes to students' answers. The systematics of writing student answers has begun to refer to the characteristics of indicators of critical thinking even though they are not perfect. The existence of this change indicates that students' mathematical critical thinking skills can be trained using methods that are considered good and effective. self-efficacy is Student known based on the results of questionnaires. After being calculated and analyzed it turns out that grade VII students have good self-efficacy when viewed from the maximum score and based on the calculations in Table 3 above. Students who feel that they have good self-efficacy will be seen from the methods and methods of working on the math problems given. Based on observations it was found that students with self-efficacy both gave fairly complete answers and there were no errors in writing answers. In other words, students with good selfefficacy will be more confident about the answers will get the best score. Efforts to increase self-efficacy students' in mathematics must be considered by a teacher because it will affect the method of solving mathematical problems.

The results obtained showed that the results of the pre-test of critical thinking skills for all students in the class taught with the models discovery learning and post-test of mathematical critical thinking skills were all different. With these differences, further testing is carried out to determine the differences that occur, so that the results obtained that students' critical thinking skills mathematically before and after learning using the model discovery learning there are differences. The results of statistical calculations obtained from the results of the test of mathematical critical thinking ability in the post-test is better than the pre-test. To ensure that there is a difference in critical thinking skills, a difference test is used using test statistics paired sample t-test. The results of the paired sample t-test as shown in the table above show that the output is significant0,000 which means that statistically there are differences in mathematical critical thinking skills before and after learning with models 
discovery learning in class VII B of Cirebon Middle School 8.

Searching the results of the pretest of mathematical critical thinking skills is still found by students who have not met the indicators of critical thinking skills. Students with previous mathematics learning experience are still less accustomed to completing complete mathematical questions according to indicators of critical thinking. But on the other hand, some students have been able to know the problems in the problem, can make observations from questions to determine mathematical information, and determine the formula that will be used to answer the questions. Students with low critical thinking ability give incomplete answers according to the purpose of the problem. Students with critical thinking skills are showing the results of good answers but cannot conclude the results of the answers. And students with high mathematical critical thinking skills are better at writing answers and giving good conclusions. In critical thinking mathematically integrates information sources of questions and prerequisite material is a mental one that students must have.

\section{CONCLUSION AND RECOMMENDATIONS \\ Conclusions}

Based on the results and discussion of research that discusses mathematical critical thinking skills in terms of self-efficacy students ', conclusions are obtained that (1) selfefficacy students' has an average of 81.45 classified as good. (2) Students' mathematical critical thinking ability has increased. (3) There is an increase in students 'critical thinking skills after learning which is viewed from selfefficacy students'.

\section{Suggestion}

This research is still lacking and there is a need for improvements to be better in providing research results. Therefore, the researchers' suggestions are as follows: (1) Students need to be given treatment special to improve selfefficacy. (2) There needs to be observation from the teacher to complete the research data. (3) The instruments used need to be validated by many educational psychologists.

\section{REFERENCES}

Aditomo, A. 2019. Pedagogical Beliefs about Critical Thinking among Indonesian Mathematics Preservice Teachers. International Journal of Instruction, 12(1).

Bong, M., \& Skaalvik, E. M. 2003. Academic self-concept and selfefficacy: How different are they really?. Educational psychology review, 15(1), 1-40.

Cervone, D. \& Lawrence A. P. 2012. Kepribadian: Teori dan Penelitian. Penerjemah: Aliya Tusyani, dkk. Jakarta: Salemba Humanika

Erwanto, E., Maryatmi, A. S., \& Budiyanto, A. 2018. The Effects of Reciprocal Teaching Learning Strategy and Self efficacy on Learning Outcomes of Early Childhood (AUD) Mathematical Logic. Al-Jabar: Jurnal Pendidikan Matematika, 9(1), 4150.

Fakhriyah, F. 2014. Penerapan Problem Based Learning dalam Upaya Mengembangkan Kemampuan Berpikir Kritis Mahasiswa. Jurnal Pendidikan IPA Indonesia, 3(1)

Feist, J., \& Feist, G. J. 2010. Teori kepribadian. Jakarta: Salemba Humanika. 
Gani, A. 2015. Pengaruh Model Pembelajaran dan Persepsi tentang Matematika terhadap Minat dan Hasil Belajar Matematika Siswa SMP Negeri di Kecamatan Salomekko Kabupaten Bone. Jurnal Daya Matematis, 3(3), 337-343.

Hardiyanto, W., \& Santoso, R. H. 2018. Efektivitas PBL setting TTW dan TPS ditinjau dari prestasi belajar, berpikir kritis dan self-efficacy siswa. Jurnal Riset Pendidikan Matematika, 5(1), 116-126.

Ikhsan, M., Munzir, S., \& Fitria, L. 2017. Kemampuan Berpikir Kritis dan Metakognisi Siswa dalam Menyelesaikan Masalah Matematika melalui Pendekatan Problem Solving. Jurnal Aksioma, 6(2), 234-245.

Kusaeri, K., Aditomo, A., Ridho, A., \& Fuad, A. (2018). Socioeconomic Status, Parental Involvement in Learning and Student'Mathematics

Achievement in Indonesian Senior High School. Cakrawala Pendidikan Jurnal Ilmiah Pendidikan, 37(3), 333-344.

Novferma, N. 2016. Analisis kesulitan dan self-efficacy siswa SMP dalam pemecahan masalah matematika berbentuk soal cerita. Jurnal Riset Pendidikan Matematika, 3(1), 76-87.

Nugraha, T., \& Mahmudi, A. 2015. Keefektifan pembelajaran berbasis masalah dan problem posing ditinjau dari kemampuan berpikir logis dan kritis. Jurnal Riset Pendidikan Matematika, 2(1), $107-120$

Pariasa, I. K., Arini, N. W., \& Japa, I. G. N. 2015. Pengaruh Pendekatan Masalah Terbuka (open-ended) terhadap Hasil belajar Matematika Siswa Kelas V SD
Gugus VII Kec. Tejakula, kab. Buleleng tahun pelajaran 2013/2014. MIMBAR PGSD Undiksha, 3(1).

Piawa, C. Y. 2010. Building a test to assess creative and critical thinking simultaneously. Procedia-Social and Behavioral Sciences, 2(2), 551-559

Sugiyono. 2007. Metode Penelitian Pendidikan Pendekatan Kuantitatif, Kualitatif, dan R\&D. Bandung: Alfabeta

Zimmerman, B. J. 2000. Self-efficacy: An essential motive to learn. Contemporary educational psychology, 25(1), 82-91. 